\title{
Cross-cultural Adaptation and Validation of the Filipino Translation of the Knee Injury and Osteoarthritis Outcome Score in Filipinos with Knee Osteoarthritis at a Tertiary Hospital
}

\author{
Ainstein Marie A. Villanueva-Misa, MD $^{1}$ and Ester G. Penserga, MD² \\ ${ }^{1}$ Philippine General Hospital, University of the Philippines Manila \\ ${ }^{2}$ College of Medicine and Philippine General Hospital, University of the Philippines Manila
}

\begin{abstract}
Objectives. 1) To translate and cross-culturally adapt the Knee Injury and Osteoarthritis Outcome Score (KOOS) into Filipino; 2) To validate the Filipino translation of KOOS using the Filipino Short-Form 36 Health Survey (SF-36) among patients with knee osteoarthritis (kOA) at a tertiary hospital.

Methodology. A Filipino version of the KOOS was translated and cross-culturally adapted from the original English version and validated following standard guidelines. Adult Fiipino patients with knee osteoarthritis at the University of the Phiippines-Philippine General Hospital were asked to complete identical questionnaires containing the Filipino KOOS and Filipino SF-36, with re-test on the same patients after a median of 14 days. Reliability was assessed using Cronbach's alpha and intraclass correlation coefficients (ICC); dimensionality using convergent and divergent construct validity.
\end{abstract}

Results. The Filipino translation of the KOOS was administered to 30 patients with knee OA (kOA). Cronbach's a across the Filipino KOOS domains ranged from 0.71 to 0.89 suggesting good internal consistency. The reproducibility of measurements of all KOOS subscales by ICC ranged from 0.97 to 1.0. For convergent construct validity, there was moderate correlation between KOOS ADL $(0.38, p=0.03)$ and knee-related QoL $(0.42, p=0.02)$ by SF-36 Physical Functioning (PF). A strong correlation (0.51, $p=0.003$ ) was observed between KOOS sports and recreation domain with SF-36 PF. For divergent construct validity, there was weak correlation between KOOS pain $(0.015$, $\mathrm{p}=0.93)$ and symptoms $(0.15, \mathrm{p}=0.42)$ with SF 36 Social Functioning.

Conclusion. The Filipino version of the KOOS is a valid and reliable instrument to measure the different aspects of disability affecting quality of life of Filipino patients with kOA.

Key Words: Filipino KOOS, knee osteoarthritis, knee injury and osteoarthritis outcome score, cross-cultural adaptation and validation

Corresponding author: Ainstein Marie A. Villanueva-Misa, MD Philippine General Hospital

University of the Philippines Manila

Taft Avenue, Ermita, Manila 1000, Philippines

Email: ainsteinmisa@gmail.com

\section{INTRODUCTION}

Osteoarthritis $(\mathrm{OA})$ is defined as end-stage joint disease, arising from multiple factors that create intra-articular stress, damage and ultimately, failed repair. ${ }^{1} \mathrm{OA}$ pathology includes progressive bone remodeling, cartilage degradation, and loss of joint space, which lead to joint pain, stiffness and loss of function, thereby, affecting the general health of an individual. ${ }^{2}$

$\mathrm{OA}$ is one of the most common joint diseases worldwide. Among adults 60 years of age or older, the prevalence of symptomatic $\mathrm{kOA}$ is approximately $10 \%$ in men and $13 \%$ in women. ${ }^{3}$ In the Philippines, the point prevalence 
of osteoarthritis is $4.1 \%$ in an urban setting, which has a population of 11 million (mean age, 34 years). ${ }^{4}$ The number of people affected with symptomatic OA is expected to increase due to the aging population and obesity epidemic. ${ }^{5}$

The Knee injury and Osteoarthritis Outcome Score (KOOS) is a disease-specific health related quality of life (HRQoL) instrument. The KOOS can be used over short and long time intervals; to monitor treatment effects from week to week, or document the course of knee injury or posttraumatic OA. ${ }^{6}$

HRQoL instruments give standardized assessment of the impact of a disease on an individual's daily living. For patients with OA, it has been shown that the KOOS can assess vast domains of importance even in groups that differ both socially and culturally. Given this, we aimed to crossculturally adapt and validate the Filipino version of the KOOS among patients with knee osteoarthritis in a tertiary hospital in Manila. The adaptation and validation of the KOOS will provide a useful tool for use among Filipinos with $\mathrm{kOA}$. It will also provide additional data on the utility of the KOOS in Asian countries. ${ }^{7}$

\section{OBJECTIVES}

\section{General Objective}

To validate the Filipino translation of the KOOS in patients with $\mathrm{kOA}$ at the University of the PhiippinesPhilippine General Hospital (UP-PGH).

\section{Specific Objectives}

1. To translate and cross-culturally adapt the KOOS into Filipino

2. To determine the convergent and divergent construct validity of the Filipino KOOS with the Filipino SF-36

\section{METHODOLOGY}

\section{Cross-Cultural Adaptation Method}

The original version of the KOOS by Ewa Roos was obtained online. Cross-cultural translation and adaptation guidelines recommended by Beaton et al. ${ }^{8}$ was used to create the Filipino version. Two independent translators translated the English version into Filipino; one was a qualified translator of the Sentro ng Wikang Filipino of the University of the Philippines and the other, a rheumatologist aware of the concepts being examined in the questionnaire. A reconciled version was developed and was back translated into English by another independent translator from the Komisyon ng Wikang Filipino. With further refinements based on the feedback from back translation, the consensus Filipino version was finalized. The forward and backward translations were reconciled into one version by a committee composed of three rheumatologists and two members of the Sentro ng Wikang Filipino. This version was used in a cognitive debriefing interview with five Filipino-speaking patients with knee OA. The version was finalized after incorporating suggestions from the KOOS developer and the patients. This final version was pilot-tested among 30 Filipino patients who have signed an informed consent form.

\section{Validation Study}

\section{Study Setting and Population}

The study was conducted at the Department of Orthopedics of the University of the PhilippinesPhilippine General Hospital, a tertiary hospital in Manila, Philippines. We included Filipino patients 40 years old and older, diagnosed with knee OA using the the American College of Rheumatology criteria for knee osteoarthritis, who understood and were able to complete the selfreport questionnaires.

\section{Data Collection}

After signing an informed consent, each participant was asked to answer the pretested questionnaires containing the Filipino KOOS and Filipino SF-36. Data on sociodemographic characteristics and co-morbidities were collected.

\section{Instruments}

The KOOS is a patient-reported outcome measurement instrument that evaluates both short-term and long-term consequences of knee injury and primary osteoarthritis (OA). It has 42 items in five separately scored subscales, namely; pain (9 items), symptoms (7 items), activities in daily living (ADL) (17 items), function in sport and recreation (5 items), and knee-related quality of life (QoL) (4 items). ${ }^{6}$ A fivepoint Likert scale that ranges from 0 (least severe) to 4 (most severe) was used as a scoring system. ${ }^{4}$ Each of the five scores in the Likert scale was calculated as the sum of the included items. A normalized score is calculated for each domain by transforming these scores to a scale from 0 to 100 , with 0 indicating functional impairment and extreme symptoms, and 100 signifying no symptoms nor functional impairment. The score calculation together with the rest of the users' guide for KOOS can be obtained online.

The SF-36 is a generic instrument which assesses "wellbeing and functional health from the patient's perspective." It is a 36 -item questionnaire which has been used globally to assess changes in health status as well as compare the burden of illness in a population. The eight areas of perceived health in SF-36 include: physical functioning (PF), role physical $(\mathrm{RP})$, bodily pain $(\mathrm{BP})$, general health $(\mathrm{GH})$, vitality $(\mathrm{VT})$, social functioning (SF), role emotional (RE) and mental health $(\mathrm{MH})$. Scores range from zero to 100 , with a higher score representing better health status. The Filipino version of the SF-36 has been validated for use in the Philippines. 
Filipino KOOS, cross cultural adaptation and validation

\section{Statistical Analysis}

We used Statistical Package for the Social Sciences (SPSS) for data management and statistical analyses. Statistical significance was defined as $\mathrm{P}<0.05$.

1. Feasibility. Feasibility was assessed using the percentages of responses and using the floor and ceiling effects in the population. Presence of floor and ceiling effects was considered if more than $15 \%$ of the respondents achieved the highest or the lowest possible scores.

2. Construct validity. Convergent and divergent construct validity was determined by comparing the results of the KOOS and SF-36 questionnaires. The Spearman's rank correlation was used to assess the association between domains. In accordance with the theoretical measurement of similar or divergent construct and results of the

Table 1. Characteristics of participants completing the Filipino KOOS

\begin{tabular}{|c|c|}
\hline Characteristic & n (\%) \\
\hline Mean age (years) & 65 \\
\hline \multicolumn{2}{|l|}{ Gender } \\
\hline Female & 29 (97) \\
\hline Male & $1(3)$ \\
\hline \multicolumn{2}{|l|}{ Status } \\
\hline Single & $2(7)$ \\
\hline Married & $25(83)$ \\
\hline Widow & $3(10)$ \\
\hline Separated & 0 \\
\hline \multicolumn{2}{|l|}{ Educational attainment } \\
\hline Elementary & $1(3)$ \\
\hline High school & $15(50)$ \\
\hline College & $14(47)$ \\
\hline \multicolumn{2}{|l|}{ Occupation } \\
\hline Homemaker & $21(70)$ \\
\hline BMI, mean & 25.9 \\
\hline \multicolumn{2}{|l|}{ Kellgren-Lawrence Score } \\
\hline 1 & 1 (3) \\
\hline 2 & $17(57)$ \\
\hline 3 & $12(40)$ \\
\hline \multicolumn{2}{|l|}{ Co-morbidities } \\
\hline HTN & $14(47)$ \\
\hline DM & $1(3)$ \\
\hline Mean duration of OA (years) & 9.03 \\
\hline \multicolumn{2}{|l|}{ Candidate for surgery } \\
\hline Yes & $11(37)$ \\
\hline No & $19(63)$ \\
\hline
\end{tabular}

KOOS, Knee injury and Osteoarthritis Outcome Score; OA, Osteoarthritis validation studies of the KOOS questionnaires in other languages, a priori hypotheses were generated for convergent, meaning moderate to strong correlation expected, and divergent, meaning weak correlation expected. ${ }^{10} \mathrm{We}$ expected the strongest correlations between scales that were supposed to measure the same or similar constructs. Since the KOOS is designed to measure physical health rather than mental health we expected to observe strong correlations between the KOOS subscales and the SF36 subscales of physical function, bodily pain, and role physical (convergent construct validity) than between KOOS subscales and the SF-36 subscales of mental health, vitality, role emotional, social functioning, and general health (divergent construct validity). ${ }^{11}$

3. Reliability. Internal consistency was assessed using Cronbach's alpha coefficient. Evaluation of the reliability used the intra-class correlation coefficient (ICC) (twoway model, single measure), with $95 \%$ confidence interval. An ICC of more than 0.80 is indicative of excellent reproducibility.

The KOOS was administered a second time after an interval of 14 days to assess test-retest reliability.

\section{RESULTS}

\section{Cross Cultural Adaptation}

The seventh item under the ADL domain in the English version was revised from "Getting in/out of car" to "Riding in and getting off a vehicle" to be more appropriate in the Filipino setting. The rest of the items in the Filipino KOOS were well understood by participants in the cognitive debriefing, and no further changes were deemed necessary. It was accepted and was used in the subsequent validation study.

\section{Validation}

\section{Participant characteristics and KOOS scores}

Thirty patients with knee osteoarthritis completed re-test interviews after a median of 14 days. Participant characteristics are shown in Table 1 . The mean age of the subjects is 65 years. Majority are females and the mean BMI is 25.9. They have long standing osteoarthritis with a mean duration of symptoms of 9.03 years. Majority have KellgrenLawrence score of 2 (56.7).

Table 2. Distribution and reliability of KOOS scores

\begin{tabular}{lccccc}
\multicolumn{1}{c}{ KOOS Domains } & Mean & Median & \% of participants at floor/ceiling & Cronbach's a & Test-retest ICC \\
Pain & 43.1 & 44.4 & 0 & 0.89 & 0.99 \\
Symptoms & 44.3 & 46.4 & 0 & 0.82 & 0.99 \\
ADL & 37.9 & 37.1 & 0 & 0.86 & 0.98 \\
Sports and Recreation Function & 15.2 & 15.8 & 23 & 0.80 & 1.00 \\
Knee-related QoL & 37.3 & 40.6 & 0 & 0.71 \\
\hline
\end{tabular}

KOOS, Knee injury and Osteoarthritis Outcome Score; ICC, intraclass correlation; ADL, Activities of daily living; QoL, Quality of life 
Filipino KOOS, cross cultural adaptation and validation

Table 3. Construct validity: correlations between the Filipino KOOS and Filipino SF-36

\begin{tabular}{llllll}
\hline \multirow{2}{*}{ Filipino SF-36 } & \multicolumn{5}{c}{ Filipino KOOS } \\
\cline { 2 - 6 } Physical & Pain & Symptom & ADL & Sports and Recreation & Knee Related QoL \\
Functioning & 0.28 & 0.40 & 0.38 & 0.52 & 0.42 \\
Role - & $0.13^{*}$ & $0.03^{*}$ & $0.04^{*}$ & $0.0034^{*}$ & $0.02^{*}$ \\
Physical & 0.16 & 0.11 & 0.09 & 0.25 & 0.25 \\
Bodily & $0.39^{*}$ & $0.56^{*}$ & $0.65^{*}$ & $0.18^{*}$ & $0.17^{*}$ \\
Pain & 0.16 & 0.34 & 0.09 & 0.11 & 0.30 \\
General & $0.39^{*}$ & $0.07^{*}$ & $0.62^{*}$ & $0.55^{*}$ & $0.12^{*}$ \\
Health & 0.25 & 0.40 & 0.19 & 0.23 & 0.41 \\
Vitality & $0.18^{*}$ & $0.03^{*}$ & $0.32^{*}$ & $0.22^{*}$ & $0.03^{*}$ \\
& 0.26 & 0.20 & 0.37 & 0.40 & 0.32 \\
Social & $0.17^{*}$ & $0.30^{*}$ & $0.04^{*}$ & $0.03^{*}$ & $0.08^{*}$ \\
Functioning & 0.02 & 0.16 & 0.01 & 0.20 & 0.30 \\
Role - & $0.94^{*}$ & $0.41^{*}$ & $0.95^{*}$ & $0.28^{*}$ & $0.11^{*}$ \\
Emotional & 0.18 & 0.06 & -0.09 & 0.26 & 0.10 \\
Mental & $0.33^{*}$ & $0.75^{*}$ & $0.62^{*}$ & $0.16^{*}$ & $0.61^{*}$ \\
Health & 0.42 & 0.36 & 0.42 & 0.33 & 0.40 \\
\hline KOOS, Knee & $0.02^{*}$ & $0.05^{*}$ & $0.02^{*}$ & $0.07^{*}$ & $0.03^{*}$ \\
\hline
\end{tabular}

KOOS, Knee injury and Osteoarthritis Outcome Score; SF, Short-Form; ADL, Activities of daily living; QoL, Quality of life Strong: Corr coefficient >0.5; Moderate: 0.5-0.35; Weak: $C<0.35$

${ }^{*} p$-value (significant correlations at $<0.05$ )

There was a floor and ceiling effect in the sports and recreation function domain with $23 \%$ of responses achieving the lowest possible score (Table 2). Missing data for the KOOS items were mainly under the sports and recreation function domain (SP2-SP4) and a few under the activities of daily living (A16-17).

\section{Assessment of psychometric properties}

Cronbach's $\alpha$ coefficients across the Filipino KOOS domains were $>0.7$, suggesting acceptable internal consistency within each domain. ICC values were also high at $>0.9$, which indicated good reproducibility and reliability of the Filipino KOOS in each subscale.

As expected, there was strong or moderate correlation between the KOOS and SF-36 scales, which were intended to measure similar constructs. Physical functioning was strongly correlated with the sport and recreation function and moderately correlated with symptom, activities of daily living and knee-related QoL. General health was moderately correlated with symptom and knee-related QoL. Vitality was moderately correlated with activities of daily living and sport and recreation domain (Table 3). In contrast, some unexpected results were obtained; in particular, moderate correlation of mental health with pain, symptom, activities of daily living, and knee-related QoL function. This was also observed in a study by Ornetti et al. Weak correlations were shown between all KOOS domains with SF-36 social functioning, physical role, bodily pain and emotional role which were expected based on previous methodological studies of the KOOS. ${ }^{12,13}$

\section{DISCUSSION}

In this study, the cross-culturally adapted Filipino version of the KOOS demonstrated acceptable psychometric properties among urban Filipino patients with knee osteoarthritis. The need to change the seventh item under the activities of daily living was apt for the Filipinos, majority of whom use public transport such as jeepneys, tricycles and buses instead of bringing their own car. This suggests that the Filipino version of the KOOS is a reliable and valid HRQoL measure in patients with knee OA in this sociocultural context.

The psychometric properties of the Filipino KOOS version were similar to the source English version. This version was shown to be reliable for group comparisons and was similar with the original KOOS as demonstrated by the Cronbach's alpha and ICC values.

Moderate correlation between KOOS ADL and kneerelated QoL with SF 36 physical functioning domain such as lifting/carrying groceries, climbing one or several flights of stairs, bending/kneeling/stooping, which measured similar constructs, strongly supports convergent construct validity. These activities are common in our population with $70 \%$ doing house chores. The sport and recreation domain did not show moderate to strong correlation with bodily pain as hypothesized. This could be due to the floor effect seen in the scores of this domain which can be attributed to the elderly population included in this study who may no longer have participated actively in sports activities. This study showed that there is a strong correlation between KOOS sports and 
recreation domain with SF physical functioning, which is consistent with the activities of the participants. We observed more correlations between the Filipino version of KOOS and Filipino SF 36 than was hypothesized.

In this study, the entire spectrum of OA may not be represented as evidenced by the predominance of KellgrenLawrence Grade 2 and 3 in the patient sample. This is further reflected in the lower construct validity and significant floor effect observed for the sport and recreation function domain, which was originally designed for physically active young patients with knee $\mathrm{OA}$ or knee injuries.

\section{CONCLUSION}

This Filipino translation of the KOOS demonstrated acceptable psychometric properties in Filipino patients with knee OA and may be used locally to capture the different aspects of functional disability affecting the quality of life of patients with knee OA.

\section{Statement of Authorship}

Both authors participated in the data collection and analysis and approved the final version submitted.

\section{Author Disclosure}

Both authors declared no conflicts of interest.

\section{Funding Source \\ None.}

\section{REFERENCES}

1. Hochberg MC. Osteoarthritis: a story of close relationship between bone and cartilage. Medicographia. 2013; 35.

2. Jones A, Silva PG, Silva AC, Colucci M, Tuffanin A, Jardim JR, et al. Impact of cane use on pain, function, general health and energy expenditure during gait in patients with knee osteoarthritis: a randomised controlled trial. Ann Rheum Dis 2012; 71:172-9.
3. Zhang Y, Jordan JM, MD. Epidemiology of osteoarthritis. Clin Geriatr Med. Aug 2010; 26(3):355-69.

4. Penserga EZ. Disease mechanisms in osteoarthritis. Philip J Intern Med. 2009; 47:231-5.

5. Lawrence RC, Felson DT, Helmick CG, Arnold LM, Choi H, Deyo RA, et al for the National Arthritis Data Workgroup. Estimates of the prevalence of arthritis and other rheumatic conditions in the United States. Part II. Arthritis Rheum. 2008; 58(1):26-35.

6. Roos EM \& Lohmander LS. The Knee injury and Osteoarthritis Outcome Score (KOOS): from joint injury to osteoarthritis. Health Qual Life Outcomes. 2003; 1:64.

7. Xie F, Li SC, Roos EM, Fong KY, Lo NN, Yeo SJ, et al. Cross-cultural adaptation and validation of Singapore English and Chinese versions of the Knee injury and Osteoarthritis Outcome Score (KOOS) in Asians with knee osteoarthritis in Singapore. Osteoarthr Cartil. 2006; 14:1098e1103.

8. Beaton DE, Bombardier C, Guillemin F and Ferraz MB. Guidelines for the process of cross-cultural adaptation of self-report measures. SPINE. 2000; 25(24):3186-91.

9. Castillo-Carandang NT, Sison OT, Grefal ML, Sy RG, Alix OC, Llanes EJ. A community-based validation study of the Short-Form 36 Version 2 Philippines (Tagalog) in two cities in the Philippines. PLoS One. 2013 Dec 26; 8(12):e83794

10. Ornetti P, Parratte S, Gossec L,Tavernier C, Argenson JN, Roos EM. Cross-cultural adaptation and validation of the French version of the Knee injury and Osteoarthritis Outcome Score (KOOS) in knee osteoarthritis patients. Osteoarthr Cartil. 2008; 16:423e428

11. Roos, Ewa and Toksvig-Larsen S. Knee injury and Osteoarthritis Outcome Score (KOOS) - validation and comparison to the WOMAC in total knee replacement. Health Qual Life Outcomes. 2003 May 25; 1:17. doi: 10.1186/1477-7525-1-17.

12. Roos EM, Roos HP, Lohmander LS, Ekdahl C, Beynnon BD. Knee Injury and Osteoarthritis Outcome Score (KOOS)--development of a self-administered outcome measure.J Orthop Sports Phys Ther. 1998 Aug; 28(2):88-96.

13. Roos EM, Roos HP, Ekdahl C, Lohmander LS. Knee injury and Osteoarthritis Outcome Score (KOOS)--validation of a Swedish version. Scand J Med Sci Sports. 1998 Dec; 8(6):439-48.

\section{The Acta Medica Philippina is now accepting limited advertising for its front and back cover (colored), as well as for available spaces in some of its pages, as appropriate. For inquiries and submission of proposals, please email us at actamedicaphilippina.upm@up.edu.ph}


Filipino KOOS, cross cultural adaptation and validation

\section{APPENDIX}

\section{Knee injury and Osteoarthritis Outcome Score (KOOS)}

\section{Sarbey sa TUHOD}

Petsa Ngayon: Petsa ng Kapanganakan:

Pangalan:

PANUTO: May kinalaman ang sarbey na ito sa inyong tuhod. Makakatulong ang impormasyong inyong ibabahagi para malaman ang inyong saloobin at kung paano ninyo nagagampanan ang mga karaniwan ninyong mga gawain.

Sagutin ang bawat tanong sa pamamagitan ng pagtsek sa iisa lamang na kahong katapat nito. Kung di naman kayo sigurado kung paano ito sasagutin, pakiusap na ibigay ninyo pa rin ang pinakamalapit ninyong kasagutan.

\section{Sintomas}

Sagutan ang mga tanong batay sa naramdaman ninyong mga sintomas sa inyong tuhod nitong NAKALIPAS NA LINGGO.

S1. Namaga ba ang inyong tuhod?
$\square$ Hindi kahit kailan
Bihira
Minsan
Madalas
Palagi

S2. Nakakaramdam ba kayo ng parang nagkikiskisan, o nakakarinig ba kayo ng "Klik" o iba pang uri ng tunog kapag iginagalaw ninyo ang inyong tuhod?
$\square$ Hindi kahit kailan
Bihira
Minsan
Madalas
Palagi

S3. Napapahinto ka ba sa paglalakad dahil pakiramdam mo lumilihis ang inyong tuhod?
$\square$ Hindi kahit kailan
$\square$ Bihira
Minsan
$\square$ Madalas
Palagi

S4. Kaya ninyo bang ituwid o iunat ng lubusan ang inyong tuhod?
$\square$ Palagi
$\square$ Madalas
$\square$ Minsan
$\square$ Madalang
Hindi kailanman

S5. Kaya ninyo bang ibaluktot ng lubusan ang inyong tuhod?
$\square$ Palagi
Madalas
Minsan
Madalang
Hindi kailanman

\section{Paninigas}

May kinalaman ang susunod na mga katanungan sa tindi ng paninigas na naranasan ninyo sa inyong tuhod nitong NAKALIPAS

NA LINGGO. Ang paninigas ay isang uri ng pakiramdam kung saan limitado o mabagal ang paggalaw ng inyong tuhod.

S6. Gaano katindi ang paninigas ng inyong tuhod sa paggising ninyo sa umaga?
$\square$ Wala
Bahagya
Katamtaman
Matindi
Napakatindi

S7. Gaano katindi ang paninigas ng inyong tuhod pagkatapos ninyong maupo, mahiga o mamahinga sa hapon?
$\square$ Wala
Bahagya
Katamtaman
$\square$ Matindi
Napakatindi

Pagkirot

PI. Gaano mo kadalas maranasan ang pagkirot ng inyong tuhod?
$\square$ Hindi kahit kalian
$\square$ Buwanan
Lingguhan
Araw-araw
Palagian

Gaano katindi ang pagkirot ng tuhod na inyong naranasan habang ginagampanan ninyo ang mga sumusunod na gawain nitong NAKALIPAS LINGGO?

P2. Pagpihit ng inyong tuhod
Wala
Bahagya
Katamtaman
Matindi
Napakatindi

P3. Pagtuwid nang lubusan ng tuhod

$\square$ Wala

Bahagya

Katamtaman

Matindi

Napakatindi

P4. Pagtiklop-tuhod
$\square$ Wala
Bahagya

Katamtaman

Matindi

Napakatindi

P5. Paglakad sa patag na daan
$\square$ Wala
$\square$ Bahagya
Katamtaman
Matindi
Napakatindi 
Filipino KOOS, cross cultural adaptation and validation

P6. Pag-akyat at pagbaba sa hagdan

$\square$ Wala $\quad \square$ Bahagya

P7. Sa gabi habang nakahiga sa kama

Wala $\quad \square$ Bahagya

$\square$ Katamtaman

Katamtaman

Matindi

Napakatindi

$\square$ Wala

Matind

Napakatindi

P8. Nakaupo o nakahiga

$\square$ Wala

Bahagya

Katamtaman

Matindi

Napakatindi

P9. Nakatayo nang tuwid
$\square$ Wala
Bahagya
Katamtaman
Matindi
Napakatindi

Pang-araw-araw na gawain

May kinalaman sa pisikal na gawain ang susunod na mga katanungan tulad ng kakayahang gumalaw at pag-aayos ng sarili. Para sa iba pang mga gawain, pakisulat kung gaano katindi ang hirap na inyong narasanan nitong NAKALIPAS NA LINGGO dahil sa inyong tuhod.

A1. Pagbaba sa hagdan
$\square$ Wala
Bahagya
Katamtaman
Matindi
Napakatindi

A2. Pag-akyat sa hagdan
$\square$ Wala
Bahagya
Katamtaman
Matindi
Napakatindi

Para sa sumusunod na gawain, pakilagay kung gaano katindi ang hirap na inyong naranasan noong isang linggo dahil sa inyong tuhod.

A3. Pagtayo mula sa pagkakaupo
$\square$ Wala
$\square$ Bahagya
Katamtaman
Matindi
Napakatindi

A4. Pagtayo

$\square$ Wala

Bahagya

Katamtaman

Matindi

Napakatindi

A5. Pagyuko sa sahig/pagpulot ng bagay

$\square$ Wala $\quad \square$ Bahagya

A6. Paglakad sa patag na lugar

$\square$ Wala

$\square$ Bahagya

Katamtaman

Katamtaman

Katamtaman

Katamtaman

Katamtaman

Katamtaman

A11. Pagtatanggal ng medyas/stocking
$\square$ Wala $\square$ Bahagya

A12. Nakahiga sa kama (pagpihit ng katawan)
Wala
Bahagya

Katamtaman

Katamtaman

Bahagya

Katamtaman

Bahagya

Katamtaman

Matind

Napakatindi 
Filipino KOOS, cross cultural adaptation and validation

Sa bawat sumusunod na gawain, pakilagay kung gaano katindi ang hirap na inyong naranasan noong NAKALIPAS NA LINGGO dahil sa inyong tuhod.

A16. Mabibigat na gawaing bahay (paglipat ng mga kahon, pagbunot ng sahig)
$\square$ Wala
Bahagya
Katamtaman
$\square$ Matindi
Napakatindi

A17. Magagaang gawaing-bahay (pagluluto, pagpupunas o pagpalis ng alikabok at iba pa)
$\square$ Wala
$\square$ Bahagya
$\square$ Katamtaman
$\square$ Matindi
Napakatindi

Gampanin, Isports at Libangan

May kinalaman ang mga sumusunod na katanungan sa inyong mas aktibong pisikal na gawain. Ibatay ninyo ang mga sagot sa tindi ng naranasan ninyong hirap sa inyong tuhod sa NAKALIPAS NA LINGGO.

SP1. Pagsquat o pagtalungko
Wala
Bahagya
Katamtaman
Matindi
Napakatindi

SP2. Pagtakbo

$\square$ Wala

Bahagya

Katamtaman

Matindi

Napakatindi

SP3. Pagtalon

$\square$ Wala

Bahagya $\square$ Katamtaman

Matindi

Napakatindi

SP4. Pag-ikot gamit ang may diprensiyang tuhod
$\square$ Wala
Bahagya
$\square$ Katamtaman
Matindi
Napakatindi

SP5. Pagluhod

$\square$ Wala

Bahagya $\square$ Katamtaman

Matindi

Napakatindi

\section{Kalidad ng Buhay}

Q1. Gaano kadalas ninyo napapansin ang problema sa tuhod?
$\square$ Hindi kahit kalian
Buwanan
Lingguhan
$\square$ Araw-araw
Palagian

Q2. Iniba mo na ba ang iyong pamumuhay upang maiwasan ang mga gawaing maaring makapinsala sa iyong tuhod?
$\square$ Hindi Iniba
$\square$ Sobrang Iniba
Bahagyang Iniba
Katamtamang Pag-iiba
Iniba lahat

Q3. Gaano ka nag-aalala sa paghina ng inyong tuhod?
$\square$ Wala
Bahagya
Katamtaman
Matindi
Napakatindi

Q4. Sa pangkalahatan, gaano katindi ang hirap na inyong nararanasan dahil sa inyong tuhod?
$\square$ Wala
$\square$ Bahagya
$\square$ Katamtaman
$\square$ Matindi
Napakatindi

Maraming salamat sa kompletong pagsagot sa talatanungang ito. 